|| ISSN(online): 2589-8698 || ISSN(print): 2589-868X || International Journal of Medical and Biomedical Studies

Available Online at www.ijmbs.info

Volume 3, Issue 2; February: 2019; Page No. 154-160

PubMed (National Library of Medicine ID: 101738825)

Index Copernicus Value 2017: 40.03

\title{
DEMOGRAPHIC AND ETIOLOGIC INVESTIGATION OF GOUT ARTHRITIS CASES IN THE KARS REGION, A COMPARATIVE RETROSPECTIVE STUDY
}

\section{Ertuğrul Allahverdi}

Kars Kafkas University Faculty of Medicine, Department of Orthopedics and Traumatology

Article Info: Received 02 February 2019; Accepted 27 February. 2019

Cite this article as: Allahverdi, E. (2019). DEMOGRAPHIC AND ETIOLOGIC INVESTIGATION OF GOUT ARTHRITIS

CASES IN THE KARS REGION, A COMPARATIVE RETROSPECTIVE STUDY. International Journal of Medical and Biomedical Studies, 3(2).

DOI: https://doi.org/10.32553/ijmbs.v3i2.133

Address for Correspondence: Ertuğrul Allahverdi, Kars Kafkas University Faculty of Medicine, Department of Orthopedics and Traumatology

Conflict of interest: No conflict of interest.

\section{Abstract}

Introduction: Gout arthritis is a very common rheumatic disorder. The hyperuricemia develops due to increased serum uric acid synthesis and/or decreased renal excretion.

Material and Method: This study was conducted after permission was obtained from the Kafkas University Ethics Committee (KAU-26-06-2018-09). We included patients who presented to the Kars Harakani State Hospital and the Kafkas University Faculty of Medicine Orthopedics and Traumatology outpatient department between May 2012 and December 2018 and were diagnosed with gout arthritis into the study. The patients were divided into two groups as Group I ( $\mathrm{n}: 87)$ consisting of patients who received Allopurinol (Xanthine Oxidase Inhibitor) at a dose of $100 \mathrm{mg} 1 \times 1$ po for 4 weeks together with a purine-poor diet (provided as a list) and Group II ( $\mathrm{n}: 77$ ) consisting of patients recommended abundant water consumption ( 2 It/day), decreased tea consumption, increased milk and dairy products consumption and a purine-poor diet (given as a list) without the administration of any drugs. Both groups were called 4 weeks later for clinical follow-up and they underwent a physical examination and laboratory evaluations at the outpatient department. Treatment protocols were evaluated comparatively according to the uric acid levels and physical examination findings.

RESULTS: Group I received a xanthine oxidase inhibitor + purine-poor diet and consisted of 5 female and 19 male patients aged 18-60 years and 17 female and 46 male patients aged 60 and over. Group II received optimal Hydration + milk and dairy products + purine-poor diet and consisted of 24 females and 53 males aged 60 and over without any patients in the 18-60 years age group. Pretreatment uric acid levels and posttreatment 4th week uric acid levels were compared.

CONCLUSION: In addition to gout arthritis treatment with drugs, it is possible to treat these patients without giving any drugs by increasing the consumption of milk and dairy products together with optimal hydration.

Key Words: Gout arthritis, Xanthine oxidase inhibitor, optimal hydration, Milk

\section{Introduction:}

Gout arthritis is a very common rheumatic disorder. Hyperuricemia (a serum uric acid level over $6.8 \mathrm{mg} / \mathrm{dL}$ ) develops following an increase in serum uric acid synthesis and/or a decrease in renal excretion. Gout arthritis is more common in males than females. Its prevalence increases in advanced age (> 75 years) and also in the postmenopausal period. The serum uric acid 
level is low and gout is therefore quite rare in the prepubertal period. Genetic abnormalities that cause elevated serum uric acid levels should be considered if the disease is seen at an early age. The asymptomatic hyperuricemia prevalence in the population is $5-8 \%$. Although the prevalence of gout varies by country, it is between $0.9 \%$ and $2.5 \%$. The prevalence in Turkey has been reported as $0.31 \%$ but the true rate is believed to be higher. The prevalence and incidence have been increasing in recent years, possibly due to various factors such as increased incidence of comorbidities, lifestyle factors, and hyperuricemia developing more commonly as a side effect with the increased use of certain drugs. Acute gout arthritis should be treated with nonsteroidal anti-inflammatory drugs (NSAIDs), colchicine or corticosteroids or a combination of two agents. Xanthine oxidase inhibitor treatment remains the first-line treatment option for the prevention of recurrent gout. $(1,2,3,4,5,15,16,17,18,21,23)$. In this study, we conducted clinical and demographic evaluations of the results of gout arthritis treatment protocols implemented in two different hospitals for cases of gout arthritis, which is common in the Kars region.

\section{Material and Method}

This study was conducted after permission was obtained from the Kafkas University Ethics Committee (KAU-26-06-2018-09). Patients who presented to the Kars Harakani State Hospital and Kafkas University Faculty of Medicine Orthopedics and Traumatology outpatient department between May 2012 and December 2018 were included. Patients diagnosed with the arthritis were divided into two groups. Group I $(n: 87)$ consisted of patients we prescribed Allopurinol (Xanthine Oxidase Inhibitor $100 \mathrm{mg}$ $1 \times 1$ po for 4 weeks) together with a purine-poor diet (given as a list). Group II ( $n: 77)$ consisted of patients recommended abundant water consumption ( $2 \mathrm{It} /$ day), increased consumption of milk and dairy products, and a purine-poor diet (given as a list) without any medication. Patients with at least one episode of swelling, pain or tenderness in a peripheral joint or bursa who received 8 points or more according to gout classification criteria in accordance with the American College of Rheumatology (ACR) / European Society for Rheumatology (EULAR) guidelines were diagnosed as gout arthritis and the groups were formed in accordance with these criteria. Both groups of patients were called 4 weeks later for the clinical follow-up and a physical examination and laboratory evaluations were performed in the outpatient department. Treatment protocols were evaluated comparatively according to the uric acid levels and physical examination findings. Patients with chronic renal failure, dialysis patients and patients being treated for psychiatric disorders, patients being treated for chronic rheumatic joint disease, patients who had undergone organ transplantation, oncology cases receiving radiotherapy and chemotherapy, and intensive care patients were excluded. Among the patients we followed-up, only 3 patients in Group 1 required surgery to remove the tophi in the 1st metatarsophalangeal joint or distal interphalangeal joint because of joint deformity, limitation of motion or inability to use the joint (Figure 1,2,3,4). Our statistical evaluations were performed with SPSS 20 and the " $\mathrm{t}$ " test between Independent Groups. All patients included in our study were assessed with their clinical evaluation data in Power Analysis.

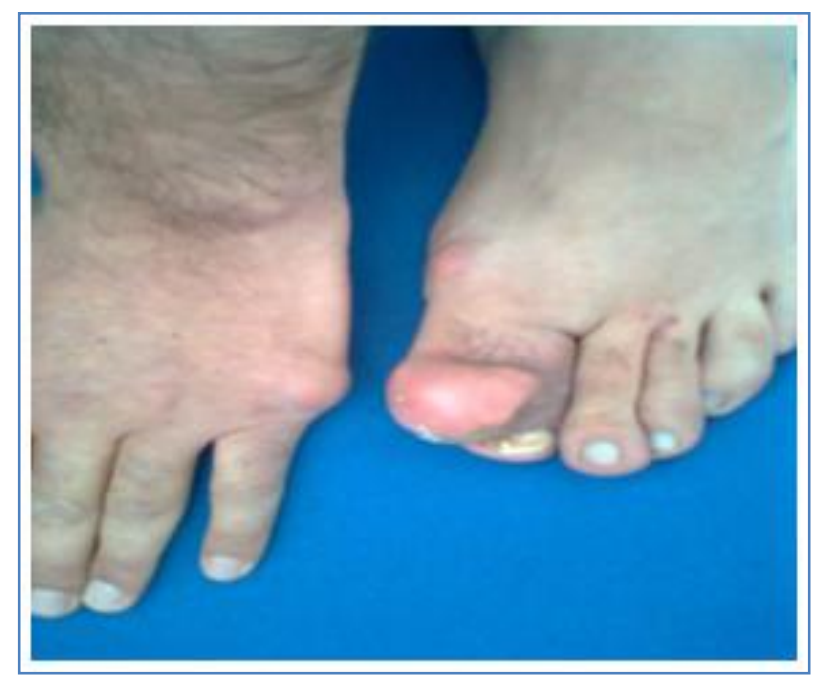

Figure 1: Gout arthritis signs in the hand and foot 


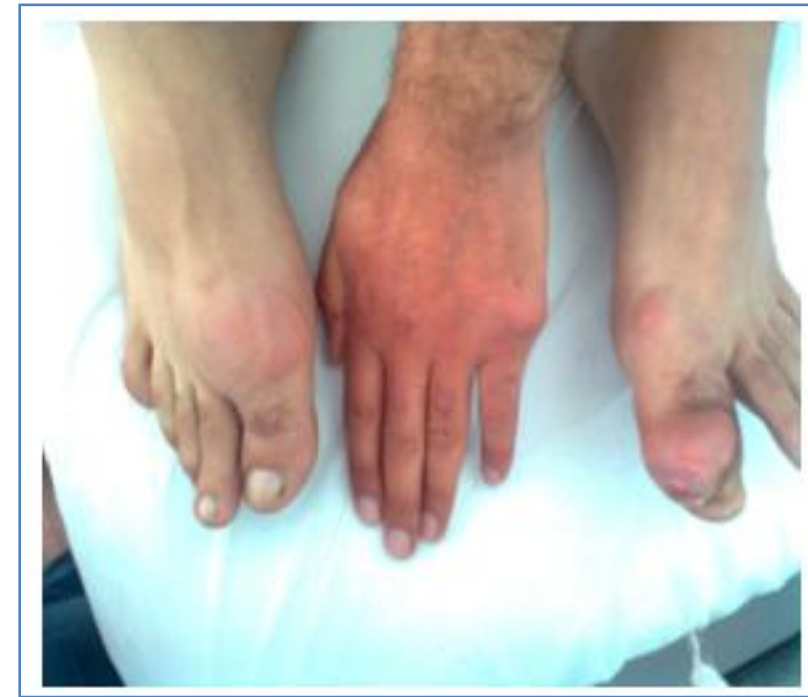

Figure 2: Bilateral gout arthritis signs in the hand and foot. Pain, movement limitation, swelling of the 5th metacarpophalangeal joint. Arthritis findings in the PIP joint and podagra in the same patient

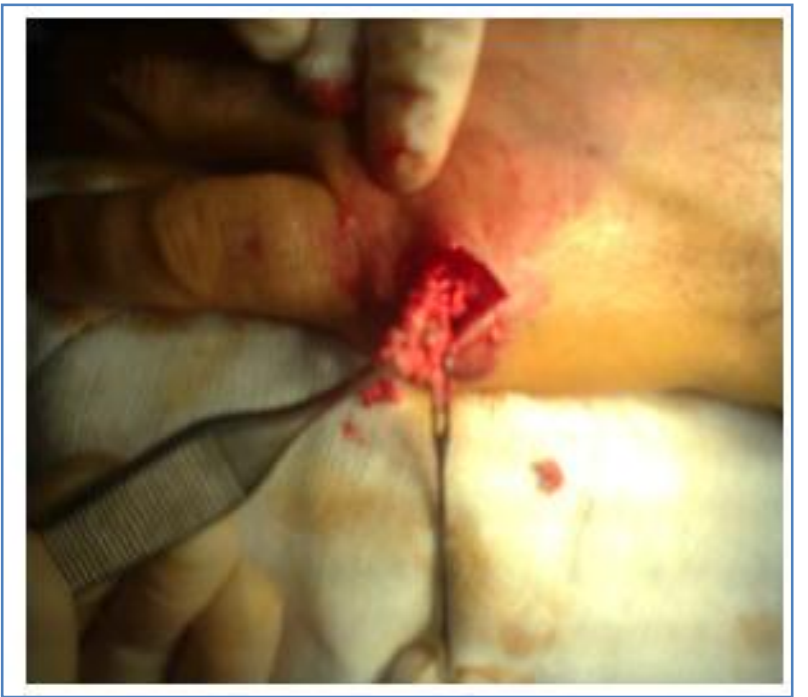

Figure 3: Excision of tophi from the metacarpophalangeal joint region by open surgery

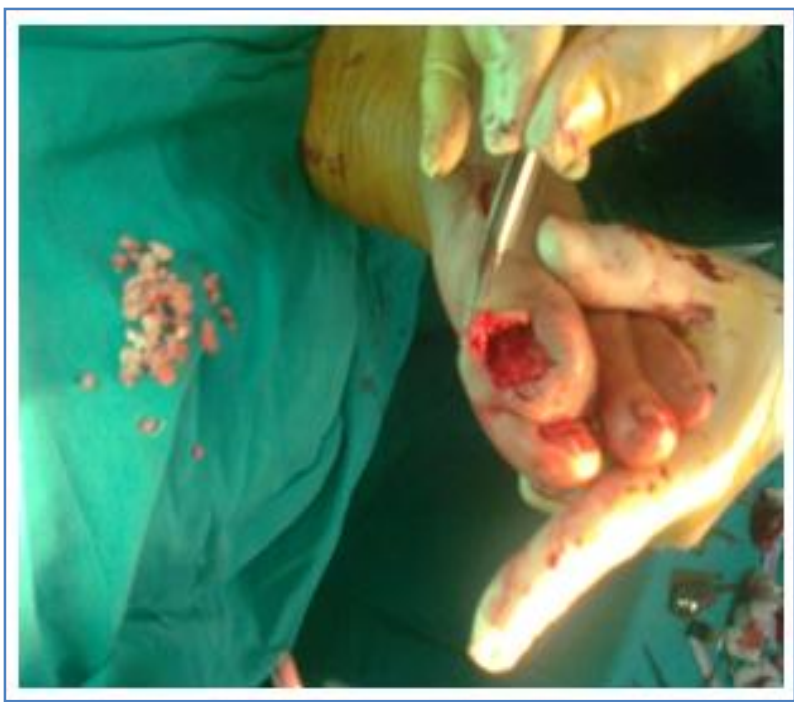

Figure 4: Excision of tophi from the metatarsophalangeal and PIP joint regions and resultant increased movement capacity in the degenerated joint

Table 1: Uric acid level by group

\begin{tabular}{|l|l|l|l|l|l|}
\hline Groups & $\mathrm{n}$ & Mean \pm SD & Min & Max & F \\
\cline { 1 - 5 } Pre-treatment & 164 & $9.10 \pm 2.20^{\mathrm{a}}$ & 6.00 & 20.10 & \\
\cline { 1 - 5 } Drugs and Diet, 4th Week & 87 & $6.74 \pm 1.63^{\mathrm{b}}$ & 2.20 & 11.90 & \multirow{2}{*}{76.33} \\
\cline { 1 - 5 } Water and Diet, 4th Week & 77 & $6.38 \pm 1.20^{\mathrm{b}}$ & 3.40 & 9.30 & \\
\cline { 1 - 5 } Total & 328 & $7.83 \pm 2.25$ & 2.20 & 20.10 & \\
\hline
\end{tabular}

$a-b$ show the statistical differences on the same line. 


\section{DISCUSSION AND CONCLUSION}

Gout arthritis is an inflammatory condition secondary to hyperuricemia caused by the accumulation of monosodium urate crystals in the intraarticular and periarticular synovial fluid and soft tissues. The solubility rate of uric acid increases at the normal body temperature of $37^{\circ} \mathrm{C}$ and $\mathrm{a} \mathrm{pH}$ of 7.4 and it is crystallized when the body temperature decreases and acidosis is present. Uric acid levels are high in most patients due to insufficient excretion through the kidneys and intestines of uric acid, the final product of purine metabolism. The prevalence of gout is increasing worldwide due to changing nutritional habits and decreasing the quality of life, similar to other disorders $(1,2,3,4,5,6,9)$. Gout arthritis is more common in men than in women. The prevalence increases in both genders in advanced age. In our study, there were 118 male patients and 46 female patients. There were 46 males above and 19 below the age of 60 . The respective numbers for the females were 41 and 5. These results are similar to other studies in the literature.

Updated guidelines for gout treatment were published in 2012 by the American College of Rheumatology ( $A C R$ ) and underlined the need for comprehensive treatment in patients diagnosed with gout arthritis. According to the European League against Rheumatism (EULAR), treatment of comorbidities (renal failure, hypertension, ischemic heart disease, heart failure, and inflammatory bowel diseases such as ulcerative colitis and Crohn's disease), lifestyle changes and correct nutrition could be important $(1,2,3,4,7,8,10,11,12,15,16,17,18,19,23)$.

Orthopedic patients with at least one episode of swelling, pain or tenderness in a peripheral joint or bursa who received 8 points or more in accordance with the American College of Rheumatology (ACR)/European League Against Theumatism (EULAR) guidelines were diagnosed as gout arthritis and included in our study (23). The basic nutrition of the Kars region in Eastern Anatolia is based on bovine meat with significantly lower comsumption of ovine meat (sheep, goats). There have been many studies on various drug treatments and durations for acute and chronic gout arthritis, and new treatment approaches with new drugs have provided current information $(6,7,8,12,22,23)$. In addition to medical therapies, the basic principles of nutritional therapy in conventional medicine mainly include limiting the amount of purine in the diet and reaching the appropriate body weight, and also emphasize increased consumption of milk and dairy products and fluids, especially water, to maintain the glomerular filtration rate at or above physiological levels (GFR> $60 \mathrm{ml} / \mathrm{min} / 1.73 \mathrm{~m}^{2}$ ) $(1,2,3,4,8,16,17,23)$. Besides, certain food components may affect the plasma uric acid plasma level through mechanisms not related to the purine load $(2,3,4,8,10,16,17,18,19,20,23)$. Radon inhalation and radon-containing hot spring waters have been shown to be useful in the hydration treatment of hyperuricemia in certain studies conducted on rats (13). Consumption of giblets, red meat and meat products on most days of the week and excessive daily consumption of tea was found in the history of all our patients. The optimal hydration rate was found to be quite low in both our patient groups due to excessive consumption of tea. Tea consumption is quite high in the Kars region and we have confirmed in another study that tea may have an increasing effect on urate levels $(2,3,4,6)$. The majority of the populations in the Kars region have low consumption of urate-increasing vegetables, ready-made fruit juices, alcohol, coffee and fish due to the reflection of the cultural and living conditions on their eating habits. Xanthine oxidase is responsible for converting hypoxanthine into xanthine and then xanthine into uric acid during purine synthesis. Administration of xanthine oxidase inhibitors results in decreased uric acid formation. At the same time, xanthine oxidase inhibitors decrease uric acid in acute gout arthritis developing due to overproduction of uric acid. Xanthine oxidase inhibitors are the first choice of treatment in the prevention of recurrent gout arthritis. The initial daily dose 
should not exceed $100 \quad \mathrm{mg}$ $(7,8,9,11,12,14,15,16,21,22,23)$. Another recommended treatment option for gout arthritis was optimal hydration and increased milk and dairy product consumption in the study conducted by Khanna et al. The consumption of milk and dairy products have a place in the treatment of gout arthritis caused by hyperuricemia as they increase the fractional excretion of xanthine (24). The endogenously bioactive peptides in milk have also been shown to have immune (antibacterial, antiviral), anticancerogenic, antioxidant, anti-infammatory, antithrombotic and hypocholesteroemic effects in cardiovascular pathologies and arthritis caused by hyperuricemia $(25,26)$.

Allopurinol, a xanthine oxidase inhibitor, was prescribed to the patients as a daily single dose of $100 \mathrm{mg}$ in our study. A dose increase was not required in any of our patients. The baseline symptoms were seen to regress at the 4th week in both the patients prescribed a xanthine oxidase inhibitor and those who consumed an increased amount of milk and dairy products and ensured optimal hydration. The use of a xanthine oxidase inhibitor and optimal hydration together with increased consumption of milk and dairy products were both seen to be similarly effective in the statistical analysis performed.

In conclusion, it is possible to treat gout arthritis patients by increasing the consumption of milk and dairy products and with optimal hydration without administering any medication as an alternative to drug treatment.

\section{REFERENCES}

1. Tausche A.K., Aringer M., Gicht. Zeitschrift für Rheumatologie November 2016, Volume 75, Issue 9, pp 885-898

2. Kolasinski SL. Food, drink, and herbs: alternative therapies and gout. Curr Rheumatol Rep. 2014 Apr;16(4):409. doi: 10.1007/s11926-014-0409-8.

3. Beyl R. N., Hughes L., Morgan S. Update on Importance of Diet in Gout. American Journal of Medicine, 2016-11-01, Volume
129, Issue 11, Pages 1153-1158, Copyright $(\subset$ 2016 Elsevier Inc.

4. Choi HK . A prescription for lifestyle change in patients with hyperuricemia and gout. Curr Opin Rheumatol. 2010 Mar;22(2):16572. doi: 10.1097/BOR.0b013e328335ef38.

5. Dalbeth N, Merriman TR, Stamp LK Gout. Lancet. 2016 Oct 22;388(10055):2039-2052. doi: 10.1016/S0140-6736(16)00346-9. Epub 2016 Apr 21.

6. Major TJ, Topless RK, Dalbeth N, Merriman TR. Evaluation of the diet wide contribution to serum urate levels: meta-analysis of population based cohorts. BMJ. 2018 Oct 10;363:k3951. doi: 10.1136/bmj.k3951.

7. Nuki G. An appraisal of the 2012 American College of Rheumatology Guidelines for the Management of Gout. Curr Opin Rheumatol. 2014 Mar;26(2):152-61. doi: 10.1097/BOR. 0000000000000034.

8. Khanna D1, Fitzgerald JD, Khanna PP, Bae S, Singh MK, Neogi T, Pillinger MH, Merill J, Lee S, Prakash S, Kaldas M, Gogia M, Perez-Ruiz F, Taylor W, Lioté $F$, Choi $H$, Singh JA, Dalbeth $N$, Kaplan $S$, Niyyar $V$, Jones D, Yarows SA, Roessler B, Kerr G, King C, Levy G, Furst $D E$, Edwards NL, Mandell $B$, Schumacher HR, Robbins $M$, Wenger $N$, Terkeltaub R. American College of Rheumatology. 2012 American College of Rheumatology guidelines for management of gout. Part 1: systematic nonpharmacologic and pharmacologic therapeutic approaches to hyperuricemia. Arthritis Care Res (Hoboken). 2012 Oct;64(10):1431-46. doi: 10.1002/acr.21772.

9. U. Kiltz, R. Alten, M. Fleck, K. Krüger, B. Manger, U. Müller-Ladner, H. Nüsslein, M. Reuss-Borst, A. Schwarting, H. SchulzeKoops, A. Tausche, J. Braun Langfassung zur S2e-Leitlinie Gichtarthritis (fachärztlich) Evidenzbasierte Leitlinie der Deutschen Gesellschaft für Rheumatologie (DGRh) Leitlinie der Deutschen Gesellschaft für Rheumatologie( AWMF-Leitlinien Register Nummer: 060/005, Entwicklungsstufe: S2e 
https://dgrh.de/dam/.../20160712_Langfass ung_Gicht.pdf

10. Sautner, G. Eberl, G. Eichbauer-Sturm, J. Gruber, R. Puchner, P. Spellitz, C. Strehblow, J. Zwerina Ernährungs- und Lebens stilempfehlungen bei Gicht und Hyperurikämie Diese Empfehlungen wurden vom ÖGR-Arbeitskreis für Arthrose und Kristallarthropathien erstellt. (c) 2014 Österreichische Gesellschaft für Rheumatologie \& Rehabilitation https:// rheumatologie.at/.../OeGR_Ernaehrungsem pfehlung-...

11. W Zhang, M Doherty, T Bardin, E Pascual, V Barskova, P Conaghan, J Gerster, J Jacobs, B Leeb, F Lioté, G McCarthy, P Netter, G Nuki, F Perez-Ruiz, A Pignone, J Pimentão, L Punzi, E Roddy, T Uhlig, and I Zimmermann-Gòrska. EULAR evidence based recommendations for gout. Part II: Management. Report of a task force of the EULAR Standing Committee For International Clinical Studies Including Therapeutics (ESCISIT). Ann Rheum Dis. 2006 Oct; 65(10): 1312-1324.

12. Latourte A., Bardin T., Richette P. Prophylaxis for acute gout flares after initiation of urate-lowering therapy Rheumatology, Volume 53, Issue 11, 1 November 2014,1920-1926,

13. Etani R, Kataoka T, Kanzaki N, Sakoda A, Tanaka H, Ishimori Y. Mitsunobu F, Yamaoka K. Difference in the action mechanism of radon inhalation and radon hot spring water drinking in suppression of hyperuricemia in mice. J Radiat Res. 2016 Jun; 57(3): 250-257. Published online 2016 Jun 21. doi: 10.1093/jrr/rrw014

14. Roddy E., Choi H.K. Epidemiology of Gout. Rheumatic Disease Clinics of North America, 2014-05-01, Volume 40, Issue 2, 155-175

15. Yardım N., Kocadag S., Kelat E.Z. Tiroid, Osteoporoz, Gut - Halk Sağlığı Genel Müdürlüğü T.C Sağlık Bakanlığı Ankara 2017,12-13,19-24

16. Gröbner W, Zöllner N. Gout. Z Rheumatol. 2004 Feb;63(1):2-9.
17. Kiedrowski M, Gajewska D, Włodarek D. The principles of nutrition therapy of gout and hyperuricemia. Pol Merkur Lekarski. 2014 Aug;37(218):115-8.

18. Jubair WK, Hendrickson JD, Severs EL, Schulz HM, Adhikari S, Ir D, Pagan J, Anthony R, Robertson CE, Frank DN, Banda NK, Kuhn KA. Modulation of inflammatory arthritis by gut microbiota through mucosal inflammation and autoantibody generation. Arthritis Rheumatol. 2018 Mar 13. doi: 10.1002/ art.40490.

19. Pisetsky DS. How the gut inflames the joints. Ann Rheum Dis. 2018 May;77(5):634-635. doi: $\quad 10.1136 /$ annrheumdis-2018-212942. Epub 2018 Mar 2.

20. Kiedrowski M, Gajewska D, Włodarek D. The principles of nutrition therapy of gout and hyperuricemia. Pol Merkur Lekarski. 2014 Aug;37(218):115-8.

21. Latourte A, Bardin T, Richette P. Prophylaxis for acute gout flares after initiation of uratelowering therapy. Rheumatology (Oxford). 2014 Nov;53(11):1920-6. doi: 10.1093/ rheumatology/keu157. Epub 2014 Apr 23. Review.

22. Schlesinger N. Treatment of chronic gouty arthritis: it is not just about urate-lowering therapy. Semin Arthritis Rheum. 2012 Oct;42(2):155-65. doi: 10.1016/j.semarthrit. 2012.03.010. Epub 2012 Apr 26. Review.

23. Wilson L, Sasen J.J. Gouty Arthritis: A Review of Acute Management and Prevention. 18 June 2016 https://doi.org/10.1002/phar. 1788

24. Dalbeth N, Wong S, Gamble GD, Horne A, Mason B, Pool B, Fairbanks L, McQueen FM, Cornish J, Reid IR, Palmano K Acute effect of milk on serum urate concentrations: a randomised controlled crossover trial. Ann Rheum Dis. 2010 Sep;69(9):1677-82. doi: 10.1136/ard.2009. 124230. Epub 2010 May 14.

25. Kanekanian A Milk and Dairy Products as Functional Foods. 2014.https://books. google.com.tr/booksisbn=1118635086. 
Ertuğrul Allahverdi, International Journal of Medical and Biomedical Studies (IJMBS)

26. Kocic G, Sokolovic D, Jevtovic T, Cvetkovic $T$, Veljkovic A, Kocic $\quad H$, Stojanovic S, Jovanovic A, Jovanovic J, Zivkovic P. Short communication: Effect of commercial or depurinized milk diet on plasma advanced oxidation protein products, cardiovascular markers, and bone marrow CD34+ stem cell potential in rat experimental hyperuricemia. J Dairy Sci. 2014 Nov;97(11):6823-7. doi: 10.3168/jds.2014-8556. Epub 2014 Sep 11. 